\title{
MENINGKATKAN KEMAMPUAN BERPIKIR SIMBOLIK ANAK USIA DINI KELOMPOK A (USIA 4-5 TAHUN) DENGAN MEDIA PEMBELAJARAN LESUNG ANGKA
}

\author{
Ani Bodedarsyah ${ }^{1}$, Rita Yulianti ${ }^{2}$ \\ ${ }^{1}$ Institut Keguruan dan Ilmu Pendidikan (IKIP) Siliwangi, Cimahi. \\ ${ }^{2}$ Institut Keguruan dan Ilmu Pendidikan (IKIP) Siliwangi, Cimahi. \\ 1anianyelir@gmail.com, ${ }^{2}$ ritayulianti613@gmail.com
}

\begin{abstract}
Cognitive development is an important aspect. One of them is the ability to think symbolically. To improve the ability of symbolic thinking of early childhood certainly cannot be separated from the role of educators. Indicators of cognitive development that must be achieved by children aged 4-5 years are: numbers 1-10, recognizing the concept of numbers, recognizing the symbol of numbers, and recognizing the symbol of letters. For this reason, it is appropriate for educators to work hard to improve the ability to think symbolically in early childhood by providing stimulation through appropriate learning media like children, one of which is the media learning of dimples. This research was conducted with a class action research method. From the two cycles that have been done show the results that there is an increase in the ability of symbolic thinking in early childhood group A using the media learning dimples.
\end{abstract}

Keywords: Symbolic thinking, Dimples

\begin{abstract}
Abstrak
Perkembangan kognitif merupakan aspek yang tidak kalah penting. Salah satunya adalah kemampuan berpikir simbolik. Untuk meningkatkan kemampuan berpikir simbolik anak usia dini tentu tak lepas dari peranan pendidik. Indikator perkembangan kognitif yang harus dicapai anak usi 4-5 tahun adalah: membilang benda 1-10, mengenal konsep bilangan, mengenal lambang bilangan, dan mengenal lambang huruf. Untuk itu sudah selayaknya pendidik berusaha dengan keras untuk meningkatkan kemampuan berpikir simbolik anak usia dini dengan cara memberikan stimulasi melalui media pembelajaran yang tepat bagai anak, salah satunya adalah media pembelajaran lesung angka. Penelitian ini dilakukan dengan metode peneletian tindakan kelas. Dari dua siklus yang telah dilakukan menunjukkan hasil bahwa terdapat peningkatan kemmapuan berpikir simbolik pada anak usia dini kelompok A dengan menggunakan media pembelajaran lesung angka.
\end{abstract}

Kata Kunci: Berpikir simbolik, Lesung Angka 


\section{JURNAL CERIA}

ISSN : 2614-6347 (Print) 2714-4107 (Online)

Vol.2 | No.6 | November 2019

\section{PENDAHULUAN}

Perkembangan kognitif

merupakan asfek yang tidak kalah penting dalam ke 6 asfek perkembangan anak usia dini yang harus dicapai. Perkembangan kognitif berhubungan langsung denagan kegiatan berpikir dan bagaimana bagaiman kegiatan berpikir itu bekerja. Faktor kognitif merupakan peranan penting bagi keberhasilan dalam belajar, karena sebagian aktifitas dalam belajar sellau berhubungan langsung dengan mengingat dan berpikir. Untuk perkembangan kognitif anak yang harus dicapai salah satunya adalah kemampuan berpikir simbolik.

Menurut Piaget perkembangn kognitif dibagi menjadi 4 tahapan yaitu sensori motoris (usia lahir-2 tahun), pa-operasional (usia 2-7 tahun), operasional konkret (usia 7-11 tahun), dan operasional formal (usia 7-11 tahun). Pada akhir tahapan sensori motoris anak sudah bisa menhasilkan pola-pola sensori motor yang komplek dan menggunakan simbol-simbol primitif (Santrock, 2008. Hlm. 245)

Piaget dalam teorinya menyebutkan pada tahapan pra-operasional (usia 2-7 tahun), anak sudah mulai mempresentasikan dunianya dengan kata-kata, bayangan, dan gambar-gambar. Pada tahapan ini anak akan mengembangakan kemampuan untuk menggambarakan sebuah obyek yang tidak ada (Santrock, 2008. Hlm. 251)

Dalam peraturan mentri no 137 tahun 2014 tentang standar tingkat pencapaian perkembangan asfek kognitif dalam berpikir simbolik yang harus dicapai pada anak usia 4-5 tahun adalah: membilang bnayaknya benda 1-10, mengenal lambang bilangan 1-10, mengenal konsep bilangan dan mengenal lambang huruf. ((https://www.paud.id/2015/09/t//ingkatperkembangan-anak-usia-4-5-tahun.htm l), n.d.)

Anak usia dini adalah sosok individu yang berada pada rentang usi 0-6 tahun yang merupakan usia emas (golden age) dimana pada ,asa ini merupakan masa sensitive segala potensi yang dimiliki anak untuk berkembang. (DIkMAS, 2016. Hlm. 2) Pembentukan SDM berkualitas mealui pendidikan yang berkualitas harus dimulai sejak dini. Pendidikan anak usia dini memiliki peran yang sangat menentukan, karena pada usia ini berawal dimulainya semua pertumbuhan dan perkemabangan. Keberhasilan dalam perkembangannya saat ini akan menentukan perkembangannya di masa mendatang. Ada 6 asPek perkembangan yang harus dicapai oleh anak usia dini yaitu: nilai agama dan moral, fisik motoric, kognitif, Bahasa, social emosinal dan seni.

Kemampuan berpikir simbolik merupakan salah satu asfek yang termasuk kedalam perkembangan kognitif yang merupakan asfek yang asangat penting yang harus dicapai dimiliki anak. Menurut piaget kemampuan berpikir simbolik adalah kemampuan untuk berpikir tentang obyek dan peristiwa, walaupun obyek dan peristiwa tersebut tidak hadir secara nyata (fisik) dihadapan anak. Kemampuan berpikir simbolik anak terjadi pada rentang usia 2-7 tahun masa ini disebut sebagai tahapan pra-operasional. (Santrock, 2008. Hlm. 252). Indicator perkembangan kognitif dalam berpikir simbolik anak usia 4-5 tahun berdasarkan standar tingkat pencapaian perkembangan anak usia dini adalah : membilang banyaknya benda 1-10, mengenal lambang bilangan 1-10, mengenal konsep bilangan dan mengenal lambang

huruf. 


\section{JURNAL CERIA}

ISSN : 2614-6347 (Print) 2714-4107 (Online)

Vol.2 | No.6 | November 2019

((https://www.paud.id/2015/09/t//ingkatperkembangan-anak-usia-4-5-tahun.htm l), n.d.)Sedangkan indicator perkembangan kognitif dalam meningkatkan kemampuan berpikir simbolik anak usia 4-5 tahun yang diambil dalam penelitian ini adalah: membilang banyaknya benda 1-10, mengenal lamabang bilangan 1-10, dan mengenal konsep bilangan. Untuk meningkatakan kemampuan berpikir simbolik anak usia dini tentunya tak bisa lepas dari peran pendidik ataupun orangtua menstimulasinya.stimulasi yang dilakukan tentunya harus menyenangkan untuk anak. Karna itu setiap kegiatan pembelajaran peranan media begitu penting untuk menyampaiakan materi yang akan diajarkan kepada anak usia dini.

Pengertian Media pembelajaran dapat dimakanai sebagai segala sesuatu yang dapat digunakan untuk menyalurkan pesan dari pengirim ke penerima sehingga dapat merangsang pikiran, perasaan, minat serta perhatian peserta didik(DIKMAS, 2016. Hlm 8)Dalam memilih jenis media pembelajaran yang tepat tentunya tak pernah lepas dari peranan guru. Guru harus bisa memilih jenis media pembeljaran apa yang akan digunakan untuk menyampaiakn materi yang akan diberikan pada anak ketika kegiatan pembelajran. Media pembelajaran yang digunakan untuk meningkatkan kemampuan berpikir simbolik anak usia dini yang paling tepat menurut peneliti adalah media pembelajaran lesung angka.

Pengertian Lesung itu sendiri adalah lumpang kayu panjang yang dipakai untuk menumbuk padi (Pusat, n.d. Hlm. 821)Lesung angka adalah suatu media atau alat bantu yang terbuat dari balok/ kayu dan bentuk fisiknya hampir mirif dengan lesung yang berukuran mini.

Menurut Hennich and Molenda ada 6 jenis dasar dari media pembelajaran, salah satunya yaitu: benda-benda tiruan/ miniatur. Termasuk didalamnya benda-benda tiga dimensi yang dapat disentuh dan diraba oleh siswa. (https://webmediapembeljaran.wrdpress. co/2016/12/30/hennich/), n.d.)Merujuk pada pemaparn diatas media pembelajaran lesung angka adalah termasuk jenis benda-benda tiruan atau miniature. Media ini termasuk media pembelajaran tiga dimensi yang dapat diraba, disentuh dan dimainkan.

\section{METODOLOGI}

Metode penelitian yang dilakukan dalam penelitian ini adalah metode penelitian tindakan kelas (classroomacyion research). PTK merupakan studi sistematis yang dilakukan oleh guru dalam upaya memperbaiki praktik praktik dalam pendidikan dengan melakukan tindakan praktis sera refleksi dari tindakan tersebut (Hendriana, 2017. Hlm. 33)Penelitian tindakan kelas dilakukan untuk mengatasi berbagai masalah yang terjadi dalam pendidikan dan pembejaran di kelas.(Hendriana, 2017. Hlm. 17)

Subjek penelitian ini adalah seluruh siswa kelas A usi 4-5 tahun sebanyak 10 orang yang terdiri 4 orang ank laki-laki dan 6 orang anak perempuan. Teknik pengumpulan data yang digunakan adalah observasi, wawancara, dokumentasi. Dalam penelitian ini analisis datan dengan menggunakan deskriptif kuantitatif dan kualitatif. Data kuantitatif dipgunakan untuk memberi gambaran tentang kemampuan siswa yang sedang 


\section{JURNAL CERIA}

ISSN : 2614-6347 (Print) 2714-4107 (Online)

Vol.2 | No.6 | November 2019

ditingkatkan. Sedangkan kuantitatif digunakan untuk menganalisis data yang berupa angka.

\section{HASIL DAN PEMBAHASAN}

\section{Hasil}

Berdasarkan kondisi awal diperoleh hasil observasi meningkatkan kemampuan berpikir simbolik saat kondisi awal menunjukan siswa yang belum berkembang (BB) sebanyak $30 \%$, siswa yang mulai berkembang (MB) sebanyak $40 \%$ dan siswa yang berkembang sesuai harapan sebanyak (BSH) sebanyak 30\%.

Dengan hasil tersebut di atas, dapat ditarik kesimpulan bahwa kemampuan berpikir simbolik siswa kelompok A usia 4-5 tahun di TK Dharma Kartini 2 belum bisa berkembang secara optimal danjuga belum merata. Untuk itu diperlukan tindakan yang bisa meningkatkan kemampuan berpikir simbolik melalui stimulasi dengan menggunakan media pembelajaran lesung angka. Karena kurang optimalnya kemampuan berpikir simbolik disebabkan oleh tidak adanya media pembelajaran yang tepat untuk menyampaikan materi yang akan diberikan pada siswa. Siswa terkesan merasa bosan dengan media pembeljaran yang digunakan oleh guru yang berupa LKA.

Siklus I dilaksanakan diawali dengan melakukan perencanaan pelaksanaan kegiatan pembelajaran antara peneliti dengan guru dalam menentukan waktu, kegiatan pembelajran, pembuatan RPPH, Penyiapan media, instrumen observasi dan alat dokumentasi

Tindakan pelaksanaan dari Siklus I dilakukan selama 3 kali pertemuan. Yaitu pada tanggal 18, 25 Februari dan 4
Maret 2019. Dari hasil tes Siklus I yang dilakuakn pada tanggal 11 Maret 2019 data yang diperoleh yang belum berkembang (BB) $15 \%$, mulai berkembang (MB) $55 \%$, dan berkembang sesuai harapan(BSH) 45 Dari hasil tes siklus I terlihat menunjukan adanya perubahan peningkatan dari tes observasi awal. Tetappi peningkatan itu masih belum optimal, karena itu perlu dilanjutkan pada tahap berikutnya yaitu siklus II.

Siklus II dilakukan dengan melakukan perencanaan pelkasanaan kegiatan pembeljaran antara peneliti dan guru dalam menentukan waktu, kegiatan pembeljaran, RPPH, menyiapkan media, Instrumen obeservasi dan alat dokumentasi. Tindakan pelaksanaan pada siklus II ini, kegiatan pembeljarannya dilakukan dalm 3 kali pertemuan juga, yaitu pada tanggal 18 , 25 Maret dan 1 April 2019. Pada siklus II peneliti dan guru berusaha untuk memperbaiki kelemahan pada siklus I yang didapat dari hasil pengamatan.

Kemudian dilakukan tes observasi pada tanggal 8 April 2019, dan diperoleh data: siswa yang belum berkembanga (BB) $0 \%$, yang mulai berkembang (MB) $15 \%$ dan yang berkembang sesuai harapan (BSH). Terlihat dari hasil presentase, penghitunagan tes siklus I dan tes siklus II bahwa kemmapuan berpikir simbolik anak kelompok A (usia 4-5 tahun) menunjukan peningkatan yang cukup memuaskan. Dari hasil ini, menunjukan penelitian yang dilakuakn dengan menggunakan media pembelajaran lesung angka telah berhasil.

\section{Pembahasan}




\section{JURNAL CERIA}

ISSN : 2614-6347 (Print) 2714-4107 (Online)

Vol.2 | No.6 | November 2019

Dari hasil penelitian ini, menunjukan kegiatan belajar mengajar yang dilakukan dengan menggunakan media pembelajaran lesung angka telah berhasil meningkatkan kemmapuan berpkir simbolik anak dalam membilangng banyak benda, mengenal lambang bilangan dan mengenal konsep bilangan. Hal ini menunjukan keberdaan media pembelajaran menjadi unsur yang sangat penting dalam proses belajar mengajar. Pemilihan media pembelajarn yang sesuai dengan kondisi materi dan peserta didik yang akan diajar, tentuanya akan dapat mencapai hasil yang baik dari tujuan pembelajaran(DIkMAS, 2016. Hlm 2)

\section{KESIMPULAN}

Hasil penelitian yang tlah dilaksanakan di kelompok A (usia 4-5 tahun) di TK Dharma Kartini 2 dengan melihat hasil uraian di atas, dapat dismpulkan bahwa dengan menggunakan media pembelajran lesung angka dapat meningkatkan kemampuan berpikir simbolik. Hal tersebut dapat terlihat semakin banyaknya siswa yang meningkat kemampuan berpikir simboliknya. Hal ini tentu akan menjadi dampak positif pada langkah ayang akan diambil selanjutnya. Dimana diperlikan adanya kepandaian guru dalam memilah dan memilih media pembeljaran yang akan dipakai untuk menyampaiakan materi pada siswa.

\section{DAFTAR PUSTAKA}

(https://webmediapembelajaran.wordpre ss.co/2016/12/30/hennich/). (n.d.). No Title.

(https://www.paud.id/2015/09/t//ingkat-p erkembangan-anak-usia-4-5-tahun. html). (n.d.).

DIkMAS, P. P. (2016). Model Penumbuhan Sikap Kompetitif.

Hendriana, H. dan A. (2017). Penelitian Tindakan Kelas. Bandung: Refka Aditama.

Santrock, J.W. (2008). Perkembangan Anak. Jakarta: Erlangga.

Pusat, T. K. (n.d.). Kamus Besar Bahasa Indonesia. Jakarta: PT Gramedia Pustaka Utama 